\title{
Laços de sangue: hereditariedade e coprodução das ordens social e natural no século XIX
}

\section{I ${ }^{1}$ Claudio Roberto Cordovil-Oliveira |}

Resumo: O presente artigo, baseado em revisão bibliográfica, busca estabelecer relações entre o discurso científico acerca da hereditariedade, surgido no século XIX, e um mito, que fornecerá à burguesia pós-revolucionária de então uma oportuna arma simbólica, que conciliará a noção de justiça com a admissão do caráter natural da desigualdade social. Moldando-se à perfeição ao mito do Gênesis, a Genética, inscrevendo as diferenças em uma espécie de justiça natural, desempenhará este papel. Desta forma, vê-se como uma teoria científica se apresenta como sublimação dos fantasmas de uma sociedade. Mas se a ciência os veste, a ficção os irá despir. Por esta razão, Émile Zola, cujos romances aprofundam a dimensão mítica dos enunciados da ciência, terá aqui uma de suas obras analisadas. $\mathrm{O}$ resultado é que algo vem à luz que, de outro modo, permaneceria oculto, sob a máscara transparente da Ciência. Dito de outra forma, o seu impensado, aquilo que ela não se atreveria a verbalizar: a noção de que a falta pesa.

> Palavras-chave: hereditariedade; imaginário; coprodução; mito.
1 Escola Nacional de Saúde Pública Sergio Arouca. Rio de Janeiro-RJ, Brasil (ccordovil@ gmail.com).

Recebido em: 01/07/2015 Aprovado em: 25/09/2016 


\section{Introdução}

Este artigo busca mapear o percurso traçado por vestígios simbólico-míticos relacionados ao sangue que, já presentes no contexto histórico e na literatura do século XIX, chegam a nós através de notícias científicas atualmente veiculadas pela grande imprensa, em especial aquelas relacionadas às células-tronco adultas. Para tanto investigou-se, em uma abordagem genealógica, a constituição do discurso científico acerca da hereditariedade na França, as circunstâncias históricas de sua aparição, suas apropriações ideológicas, bem como sua releitura pela literatura contemporânea, a partir de um romance de Émile Zola, O Doutor Pascal, publicado em 1893.

A estratégia metodológica aqui adotada não somente concebeu os mitos presentes em notícias dessa natureza como atávicas manobras de manutenção do status quo voltadas para a criação de consensos, mas também reitera a pertinência do nexo entre natureza e sociedade (ou ordem natural e ordem social), sugerido pela abordagem interpretativa que se convencionou chamar de “'idioma' da coprodução". Nesse sentido, esta reflexão filia-se ao campo dos Estudos Sociais da Ciência e Tecnologia, cujos métodos se nos afiguram como indispensáveis para a análise adequada das correlações entre poder, cultura e mudança social, em toda sua complexidade (JASANOFF, 2004).

O recurso à mencionada abordagem interpretativa da coprodução se justificaria pelo fato de, segundo alguns autores, ser impossível refletir sobre tecnologias nascentes, doenças emergentes e o crescimento da internet, empregando-se conceitos da teoria social tradicional e suas habituais dicotomias: estrutura/ agência; natureza/cultura; ciência/política e estado/sociedade (JASANOFF, 2004). Acredita-se que tais abordagens convencionais, que enfatizam uma compreensão dualística da relação entre homem e natureza, não deem conta dos processos irregulares e dinâmicos através dos quais a produção de Ciência, Tecnologia e Inovação (CT\&I) vincula-se a hierarquias e normas sociais.

\section{Uma nova relação com o mito}

As relações entre jornalismo e mito foram objeto de interesse do campo dos Cultural Studies, principalmente nas décadas de 1970 e 1980 (MAIA, 2010). Para 
Carey (1975), as notícias devem ser compreendidas como sistemas simbólicos que representam e reforçam visões de mundo particulares. Há quem as veja como ocupando o lugar que era reservado aos mitos nas sociedades arcaicas (BIRD; DARDENNE, 1993; LULE, 2001; 2005). Retomando Barthes (1993), Maia (2010, p. 3) irá afirmar que nesse sentido caberia ao jornalismo naturalizar a História, "transformando contingência em eternidade".

Este artigo tem como uma de suas finalidades estabelecer um diálogo entre a Teoria do Imaginário, os Estudos Sociais de Ciência e Tecnologia e os Estudos de Jornalismo, visando desvelar a função ideológica dos enunciados científicos, especialmente no campo da Biomedicina. Como espinha dorsal deste texto, destaca-se o alerta de Vattimo sobre o processo de secularização no Ocidente.

A secularização do espírito europeu da idade moderna não é apenas a descoberta
e a desmitificação dos erros da religião, mas também a sobrevivência, em formas
diversas, e num certo sentido degradadas, daqueles 'erros'. Uma cultura secularizada
não é uma cultura que tenha simplesmente atirado para trás das costas os conteúdos
religiosos da tradição, mas que continua a vivê-los como vestígios, modelos ocultos e
deturpados, mas profundamente presentes (VATTIMO, 1992, p. 47).

Gilbert Durand, em obra seminal (2002), sistematizou a teoria do imaginário a partir de três conceitos centrais: arquétipo, símbolo e mito. De especial interesse para os fins deste artigo seria o conceito de "mito": "sistema de arquétipos e símbolos organizados em torno de uma narrativa que reúne os fundamentos de uma cultura e os sedimenta na memória coletiva”. Durand irá ressignificar o conceito de mito, tão caro aos antropólogos, para defini-lo como um "sistema dinâmico de símbolos, arquétipos e esquemas; sistema dinâmico que, sob o impulso de um esquema, tende a compor-se em narrativa" (DURAND, 2002). Maia esclarece que: "Os arquétipos são anteriores à história; só produzem significados quando entram em interação com o ambiente cultural e fazem emergir os símbolos e mitos - e, logo, os imaginários - que unem e movem uma comunidade" (2010, p. 6).

Em atitude mais coerente com os novos tempos, na perspectiva adotada por Vattimo (1992), propõe-se aqui o emprego renovado do mito durandiano, para compreender fenômenos como aqueles representados na figura 1. Nesse sentido, promover aqui um diálogo com a abordagem interpretativa da coprodução nos parece estratégia metodológica acertada. 

eficácia retórica

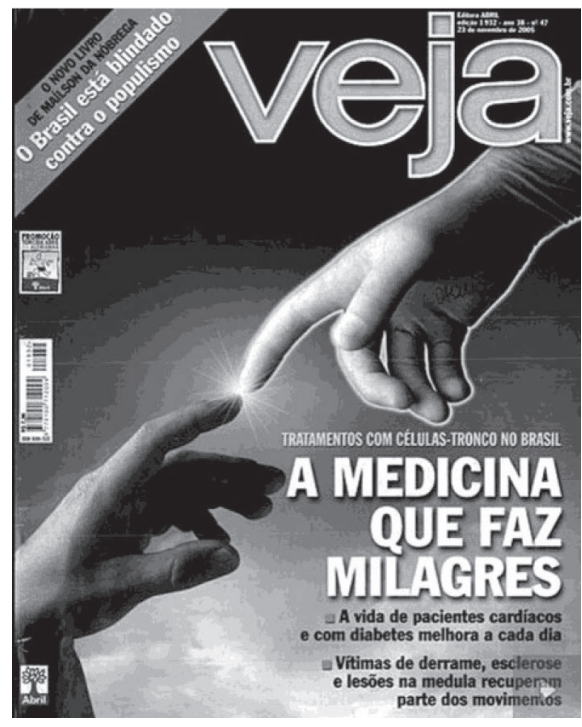

Fonte: Revista Veja, Rio de Janeiro, 22 nov. 2005

\section{O debate construtivismo versus realismo: a coprodução como abordagem interpretativa}

Pellizzoni (2014), em esclarecedor artigo, traça o percurso histórico do debate sobre realismo versus construcionismo, que, segundo o autor, nada mais faz do que replicar antiga controvérsia filosófica sobre a constituição da natureza e nosso acesso cognitivo à mesma, personificada principalmente nas figuras de Descartes e Kant.

Ainda sem solução aparente, segundo Pellizzoni (2014), tal debate teria-se inclinado para o reconhecimento não da primazia de um sobre o outro, mas da sua constituição mútua, agora sugerida pelo conceito de "coprodução". Por esta linha de raciocínio, entre o conhecimento e a realidade, ou entre as ordens natural e social, ou, melhor ainda, entre as ordens epistemológica e ontológica, nenhum destes entes prevaleceria sobre o outro.

"Coprodução" é termo que goza de grande popularidade entre os pesquisadores vinculados aos Estudos Sociais de Ciência e Tecnologia. Ao redor de seu campo semântico também gravitam expressões surgidas na década de 1990, como "ciborgues", "híbridos", "assemblages", "constituição mútua”, etc. No 
entanto, segundo Jasanoff (2004), não seria correto afirmar que ele seria objeto

de uma teoria coerente. Deve-se, isto sim, vê-lo como um “idioma”, uma área do pensamento que compartilha determinados elementos:

Um é o reconhecimento de que o que consideramos como fatos inquestionáveis sobre
a realidade física são conquistas sociais importantes e variáveis de um setting cultu-
ral e histórico para outro. Outro é a compreensão de que tecnologias supostamente
inanimadas - tais como a engenharia genética, as usinas nucleares, os telescópios
espaciais ou as bases de dados computacionais - efetivamente incorporam crenças
e práticas sociais, tais como regras legais ou julgamentos culturais sobre a Justiça.
Outro ainda seria o fato de que a capacidade de produzir formas particulares de co-
nhecimento e compreensão científica estaria indissoluvelmente ligada a outros tipos
de capacidade política e social (EZRAHI, 1990 apud. JASANOFF, 2004, p. 67).

Coprodução diz respeito a certa intuição de que se ganharia poder explanatório acerca de amplas áreas da atividade humana, presente e passada, quando se optasse por pensar que as ordens natural e social são produzidas simultaneamente, através de complexas inter-relações (JASANOFF, 2004). Ou, em outras palavras, perceber que práticas de governança influenciam a construção e o emprego de conhecimentos e vice-versa. A corroborar tal insight, destacam-se alguns clássicos da sociologia do conhecimento científico (BIJKER; HUGHES; PINCH, 1987; MACKENZIE, 1990; SHAPIN; SCHAFFER, 2011).

Por se tratar de abordagem interpretativa, a coprodução não demandaria provas de sua pertinência, mas ilustrações de sua aplicação (JASANOFF, 2004, p. 6). Desta forma, pode-se perceber que é empregada tanto para descrever a constituição de novas culturas tecnocientíficas, sempre em torno de ideias e objetos ("variedade constitutiva"), quanto para equacionar problemas de desordem no interior de culturas estabelecidas ("variedade interacional”).

Imaginação e materialidade caminham juntas na prática científica. Andy Pickering, em The mangle of practice (1995), revela com propriedade a relação entre ambas, ao optar estrategicamente pela adoção de um idioma performativo (e não representacional) para descrever a Ciência. $\mathrm{O}$ autor irá falar em uma "dança de agências" interminável, onde os parceiros são a agência humana (dos cientistas) e a agência material (das "máquinas" sobre as quais trabalham). Assim, a prática científica poderia ser vista como uma "dialética de resistência e acomodação"; verdade e realidade dependeriam de "assemblages contingentes de entidades heterogêneas" (PICKERING, 1995). 
A importância de tais estudos reside no desafiar a afirmação da ciência como uma esfera autônoma, cujas normas seriam constituídas independentemente de outras formas de atividade social. Em vez disso, a resolução de quaisquer novos problemas científicos é vista como exigindo (re) estruturaçôes da ordem social, sem as quais a própria autoridade científica seria posta em questão. (JASANOFF, 2004, p. 30).

Intenta-se aqui demonstrar como, através de mecanismos de coprodução, a autoridade da ciência avalizou outras formas de autoridade, especialmente governamentais, e vice-versa, em conturbado período de mudança social, logo após a Revolução Francesa. Para tanto, nos basearemos nas obras de um historiador, de um médico e de um escritor franceses, contemporâneos entre si, testemunhas privilegiadas de seu tempo: Jules Michelet (1798-1874), Prosper Lucas (1808-1885) e Émile Zola (1840-1902), respectivamente.

Num segundo momento, ainda conservando em mente o conceito de coprodução, ver-se-á como tais formas de autoridade científica serão questionadas na atualidade, e posteriormente reestabilizadas, através do recurso intensivo ao que Ezrahi (2004) denominou "outformation" (em oposição ao vocábulo "information") (figura 1). "Em comparação com o conhecimento e a informação, as outformations seriam mais assimiláveis ao que hodiernamente se compreenderia como "sabedoria", ao combinar dimensões cognitivas, emocionais e estéticas, entre outras, da experiência".

\section{Hereditariedade e status quo em um contexto pós-revolucionário}

Em 1847, Jules Michelet publica sua Histoire de la Révolution Française (1939). Em sua célebre introdução, indaga a respeito das eventuais semelhanças entre o Cristianismo e a Revolução. Michelet quer saber: haveria entre esses dois sistemas continuidade ou superação, dominação ou abolição, contradição ou conciliação? Do debate por ele proposto, conclui que não se pode afirmar que a Revolução seja um momento de efetivação do Cristianismo.

Dois sistemas distintos, portanto, para Michelet, onde somente a Revolução merecerá desta testemunha ocular da história os elogios mais grandiloquentes. Se aparentemente convergiam em seus fins, esses dois sistemas, para ele, divergiam em seus princípios. Assim, para o historiador francês, a fraternidade cristã se basearia numa genealogia sagrada, de caráter vertical, enquanto a fraternidade 
revolucionária, abstrata, se assentaria no postulado racionalista da identidade de natureza entre os homens, em sua igualdade, melhor dizendo. "A Revolução fundamenta a fraternidade no amor do homem pelo homem, no dever mútuo, no Direito e na Justiça”.

Iniciada a Era da Justiça, um duplo progresso ético então se faria esperar, na visão de Michelet. Isto porque, a seu ver, com a Revolução Francesa, o arbítrio do príncipe (o Favor) daria lugar à Justiça. Esta, por sua vez, poria fim à tirania da divindade (a Graça). "A Revolução outra coisa não é do que a reação tardia da Justiça contra o império do Favor e contra a religião da Graça". Dessa forma, Michelet acreditava que a noção civil de "responsabilidade" iria finalmente destronar a noção religiosa, "bárbara e mítica”, de "fatalidade" (GAILLARD, 1981).

Michelet enganou-se. Mal saído das correntes genealógicas que o prendiam ao príncipe e a Deus, o "novo homem" festejado pelo historiador francês iria se enroscar nas malhas da fatalidade genética. De fato, o ano de 1847 também testemunhou o lançamento do primeiro tratado sobre hereditariedade de que se tem notícia (LUCAS, 1847). Seu segundo volume seria publicado em 1850.

De caráter mais fenomênico do que propriamente científico, a obra é citada por Darwin em A origem das espécies como "a melhor e mais completa" sobre o tema. Hoje é quase ilegível, dado o fato de as informações ali contidas serem extremamente datadas vis-à-vis os desenvolvimentos posteriores da Genética. É mera relíquia de um tempo passado. Prosper Lucas decididamente não figura no panteão da história oficial da Genética.

A despeito do esquecimento devotado à obra, ela tem importância histórica, por ter sido a primeira a abordar a questão da hereditariedade fora de uma perspectiva restrita a questões de criação e procriação. Até o final do século XIX, será a referência para a vulgata em torno do tema. A persistência de suas teses neste longo período sinalizaria, na visão de alguns autores, a função social a ser desempenhada por tal discurso, o que será objeto de nossa investigação neste artigo.

Mas quais seriam as implicações do surgimento desse tratado para a vida social de então, naquele exato momento histórico? Em primeiro lugar, a partir dele, a fatalidade, de teológica passaria a ser científica. Neste sentido, ela se revelará fundamental para explicar, pelas leis da natureza, a desigualdade social em uma sociedade pós-revolucionária. Passando em revista as diferentes teorias sobre 
origem e natureza dos seres vivos, o tratado de Lucas reintroduz no conturbado campo social de então a noção de "diferença", ao sustentar que a espécie é um tipo fixo, mas os indivíduos são tipos variáveis. Com Lucas, a hereditariedade passa a ser lei, muito embora não tenha sido ele que tenha formulado as leis da hereditariedade. Tal feito caberá a Gregor Mendel.

Assim, a "diferença", um eufemismo elegante para a escandalosa "desigualdade", na nova ordem social que se tenta instaurar, passa a ser inscrita na ordem natural das coisas, naturalizada, despida de seu caráter problemático por ter, como álibi e fundamento supremo, a natureza. Contra esta, não convém se rebelar. Com o tratado de Lucas, a sociedade desigual pode ficar em paz com sua consciência. A natureza, agora, assume o lugar anteriormente ocupado por Deus. O arbitrário da Graça, denunciado por Michelet, é agora habilmente substituído pelo capricho das leis genéticas, contra as quais à época pouco se poderia fazer (GAILLARD, 1981).

\section{O gene como construção histórica (e social)}

Num registro mais realista, de caráter epistemológico e absolutamente distinto daquele coproducionista ora empregado ( $\mathrm{O}$ que provavelmente confirma a pertinência do idioma da coprodução) ), o epistemólogo e historiador de ciências Andre Pichot, citando o geneticista Michel Morange, irá observar que, de fato, "o gene [e, por extensão, a hereditariedade] é uma construção histórica e social, que não existe em parte alguma" (2001). "A genética é uma ciência sem objeto": Tal afirmação de natureza tão peremptória, emitida por este ex-aluno de Georges Canguilhem, aconselha-nos a examinar com maior profundidade o artigo da qual foi extraído (PICHOT, 2001).

$\mathrm{O}$ autor inicia seu artigo problematizando afirmação de dois geneticistas em entrevista publicada na revista semestral interdisciplinar intitulada Les temps des savoirs (FAGOT-LARGEAULT; KAHN, 2000). Segundo eles, a genética seria "a ciência que estuda a transmissão dos caracteres biológicos hereditários". Pichot argumenta que não existe qualquer caracter que seja puramente hereditário, e nenhum que não o seja de algum modo.

"Dizer que a genética é a ciência dos caracteres hereditários não faz sentido algum: todos os caracteres o são e nenhum o é totalmente - da mesma forma, todos os caracteres são adquiridos, e nenhum o é totalmente". A partir de então, 
Pichot se dedica a apontar os deslizamentos epistemológicos do conceito de "gene" (e, por extensão, de "hereditariedade"), sua reconfiguração ao sabor das circunstâncias, para depois sentenciar.

Na falta de caracteres hereditários bem definidos e de genes que também o sejam,
não resta alternativa senão afirmar que a genética é uma ciência sem objeto. Isto pode
soar exagerado (sobretudo se você pensa nas representaçôes midiáticas da mesma); no
entanto, ainda que se examine ligeiramente a situação de perto, é o que acontece. A
genética não tem objeto; tem unicamente uma função. Para a compreender, necessá-
rio se faz deter-se no conceito de hereditariedade e tentar compreender o que ele reco-
bre, sem se preocupar com caracteres hereditários ou genes (PICHOT, 2001, p. 107).

A hereditariedade é uma noção de inscrição tardia no campo da biologia. Só aparece após Lamarck (1744-1829) e se desenvolve plenamente após Darwin (1809-1882). Apesar de adquirir um sentido biológico apenas na década de 1820, é somente após 1860 que o vocábulo assume uma vertente biológica mais amplamente disseminada. Em 1833, Geoffroy Saint-Hillaire, em seu Histoire générale et particulière des anomalies, assim se pronunciará a respeito da hereditariedade. "A explicação completa de todos esses fatos está fora do alcance das ciências atuais" (GAILLARD, 1994).

Proveniente do latim hereditas e sinônimo de "herança", designava inicialmente o conjunto de bens, títulos e funçōes deixadas por um homem por ocasião de sua morte e o direito de seus filhos de assumirem sua posse. As crianças herdariam caracteres biológicos e psicológicos de seus pais, como herdam bens, títulos e funçōes (PICHOT, 2001, p. 107).

Pichot dedica-se então a explicar por que teriam sido "inventadas" a hereditariedade e, por extensão, a genética. Após longas digressões epistemológicas e historiográficas, argumentará que a hereditariedade nasce de uma necessidade, inaugurada pelo lamarckismo, de articular uma explicação histórica àquela, física, dos seres vivos.

O caminho para os estudos da hereditariedade é inaugurado por Lamarck, ainda que ele mesmo jamais tenha proposto uma teoria da hereditariedade. Sua Philosophie zoologique é datada de 1809. Preocupado em explicar os seres vivos a partir, exclusivamente, de leis físicas, excluindo todo princípio vitalista ou de orientação divina, Lamarck acreditava que o surgimento de seres vivos mais complexos poderia ser explicado com a atribuição de uma espécie de apêndice histórico à sua composição físico-química. Desta forma a evolução, que atravessa 
gerações, se unirá à organização e funcionamento individual dos seres vivos atuais (PICHOT, 2001). "Tudo isso, sem a menor conceituação”, observa o autor, como a querer enfatizar o caráter de construção social (ideológica?) desses conceitos.

Segundo Pichot (2001), pode-se afirmar que a hereditariedade é um “objeto biológico não-identificado" (OBNI), pois carece de um estatuto epistemológico e não possui uma função fisiológica (como a geração ou a nutrição). Em sociologia, tais objetos são definidos como objetos de interface (boundary objects), em definição proposta por Star e Griesemer (1989).

"Objeto de interface" é conceito ligado à categoria analítica dos "mundos sociais/arenas" e designa artefatos físicos ou sociais que habitam as ligações entre diversas comunidades sociais e que têm a capacidade de harmonizar diferenças práticas e perceptuais entre as mesmas, de modo que se alcance uma compreensão comum a seu respeito que facilite a cooperação (GAL; YOO; BOLAND JR., 2005), por efeitos de translação (BOWKER; STAR, 2000; CLARKE, 2005).

Objetos fracamente estruturados no uso comum possuem, por isso mesmo, a vantagem de serem customizáveis de acordo com as mais distintas necessidades das comunidades que os empregam (BOWKER; STAR, 2000), ganhando sentidos peculiares em cada uma delas, distantes de uma verdade universal. Assim, se não tem um objeto bem identificado, a genética, na avaliação de Pichot, possui uma função, que lhe dá relevância, forma e desenvolvimento. A genética vai lançar mão do conceito de "hereditariedade" para explicar o ser vivo através de duas asserçōes complementares: uma física, ligada à fisiologia e à bioquímica; e outra histórica, ligada ao evolucionismo. Parafraseando M. Morange, Pichot afirma que a genética é o nó que une as diversas explicações biológicas dos seres vivos. "A genética avança unicamente através do progresso destas duas explicações que ela articula, sem que seus próprios esquemas explicativos sejam modificados, a não ser superficialmente" (PICHOT, 2001, p. 127).

Assim, Pichot, assumindo uma perspectiva realista no que se refere ao conhecimento, admite que a hereditariedade é uma "construção histórica", uma construção própria a determinado estado da biologia (aquele que descobre, com Lamark e depois com Darwin, a necessidade da evolução para explicar o ser vivo no quadro das leis físicas. Desta forma, irá concluir que a hereditariedade que foi inventada jamais foi definida. 
Até aqui, foi possível ver o modo pelo qual a Ciência, ao transformar em saber os fantasmas de uma sociedade - como no caso da hereditariedade (e a Genética) -, acaba por legitimá-los. De fato, a hereditariedade e a genética oferecem à burguesia nascente, por meio de certa coprodução, o mito de que esta precisara para conciliar a noção de Justiça com a naturalização da desigualdade social. Agora, intenta-se aqui mostrar como a ficção, neste caso, explorando a dimensão mítica deste saber (hereditário), o desnudará, revelando, de algum modo, o impensado da Ciência, aquilo que se esconde sob sua "máscara transparente": a noção de que a falta pesa (GAILLARD, 1994, p. 54).

Em uma era positivista como aquela representada pelo século XIX, será o discurso científico que se moldará a um mito à sua disposição, e não o contrário. Assim, veremos como o mito do Gênesis será empregado pelo escritor francês Émile Zola (1840-1902), para mais uma vez naturalizar a desigualdade social, agora no plano estético.

Neste sentido, aspectos de sua obra intitulada Les Rougon Macquart, mais especificamente seu último volume, Le Docteur Pascal (ZOLA, 1993), serão aqui brevemente analisados pelas afinidades que guardam, em sua elaboração, com o idioma da coprodução, anteriormente apresentado.

Nessa vasta obra, que congrega 20 volumes que consumiram 25 anos da vida do escritor, está colocada a tarefa, concebida por seu autor em 1868, de "escrever a história natural e social de uma família do Segundo Império" e de relatar "seu desenvolvimento no mundo moderno, em todas as classes" (GAILLARD, 1994, p. 71). Ora, ao buscar combinar, em um mesmo relato, "natureza" e "sociedade", Zola corrobora, avant la lettre, a conclusão de Bruno Latour em obra homônima, segundo a qual "jamais fomos modernos". Dito de outro modo, a máxima latouriana sugere que a sociedade "moderna" nunca funcionou da forma como a separação natureza/cultura, instauradora de seu sistema de representação do mundo, parecia sugerir. Na prática, fomos pródigos em construir objetos híbridos, que pertencem simultaneamente à natureza e à cultura, tal como a narrativa buscada na obra monumental de Émile Zola. De fato, em Les Rougon Macquart, o idioma da coprodução se faz bastante presente. 
Segundo Gaillard (1994, p. 71), para que a aposta zoliana de mesclar, em um mesmo relato, "natural" e "social” seja sustentável:

É preciso admitir que uma única e mesma causalidade presida a um só tempo a organização natural e a ordem social, vale dizer, que haja não apenas uma ausência de descontinuidade, mas também uma verdadeira identidade entre o que faz mover-se o indivíduo $[\ldots]$ e os movimentos que agem sobre o corpo social.

Adicionalmente, a extensa obra representada por Les Rougon-Macquart tem como epílogo uma robusta discussão sobre a hereditariedade, que reproduz, em uma chave simbólica, muito das discussões que, à época, mobilizavam o campo científico. Examinando esses textos literários, acreditamos ser possível buscar compreender, como era um dos objetivos deste artigo, as expectativas sociais que eram atendidas à época pelo discurso da hereditariedade, bem como constatar algo de suas ressonâncias míticas na atualidade, manifestadas em representações midiáticas contemporâneas.

Em Les Rougon-Macquart, Zola basicamente intenta retratar, em tons realistas, a sociedade de sua época, a partir do relato da saga de família homônima, em abordagem que, mais tarde, detalhará em seu Le Roman Experimental. Assim, para relatar a trajetória dessa família por todas as classes sociais, ele dividirá a sociedade em "quatro mundos": "o povo", "os comerciantes", "a burguesia" e o "grand monde". Haverá também espaço para um "mundo à parte", o das prostitutas, assassinos, padres e artistas.

Tudo começa com a matriarca e avó, Adelaide Fouque, cujo marido é Pierre Rougon. Esta tem como amante Antoine Macquart. Com ambos ela terá filhos. Os membros da família serão os heróis desta série romanesca. Entregues a seus apetites e ambições, ao longo desta obra volumosa, eles expressarão simbolicamente a influência sobre os seres humanos do meio e da hereditariedade. Estratégia literária absolutamente nova para a época (a de acompanhar uma família por gerações), esta foi vislumbrada por Zola aos 28 anos de idade, como forma de se diferenciar das celebridades de então: Balzac, Flaubert e Goncourt.

Zola concebe a ideia de encerrar a série romanesca tendo como protagonista Pascal Rougon, médico, especialista em questóes de genealogia e hereditariedade, personagem fortemente influenciado pela figura de Claude Bernard, o pai da pesquisa clínica, por quem o escritor nutria grande admiração. 
Caberá a Pascal "reunir e classificar suas observaçooes sobre a própria família”, mantendo-as atualizadas em uma árvore genealógica, a qual se dedica a investigar com especial empenho.

A partir desse momento, propusera-se o problema da concepção, o princípio de tudo,
no seu irritante mistério. Porque e como um ser novo? Quais eram as leis da vida, essa
torrente de seres que constituiam o mundo? Mas não se atinha só aos cadáveres, alar-
gava o campo das suas dissecções à humanidade viva, impressionado por certos fatos
verificados entre a sua clientela, pondo sobretudo em observação a própria família,
que se tornara o principal campo de experiência, de tal modo se lhe apresentavam nela
os casos precisos e completos (ZOLA, 1955, p. 35).

Anotações de leitura de Zola, datadas de 1868, a respeito do tratado de Prosper Lucas já mencionado, foram fundamentais para a criação do personagem, que dará título ao último volume da série. A trama, lançada em 1893, se passa entre os anos de 1872 e 1874 . O livro é uma espécie de credo do escritor "diante da cientificidade exemplar da fisiologia". Seu protagonista será um dos "últimos representantes da medicina banal do século XIX, uma medicina de cuidador, que saberá e poderá pouco, a não ser seguir com o doente até sua cura ou fim naturais" (MITERRAND, 1993, p. 39).

Obstinado em construir a árvore genealógica de sua família, em busca da "verdade proibida das origens", a falha ancestral, e em identificar e classificar suas "taras e males", vê seus esforços comprometidos pela determinação de sua mãe, Felicidade Rougon, em destruí-la e, assim, conservar segredos que representam a essência da vida burguesa: aqueles que dizem respeito às origens.

"Tara” é termo extraído da Física Mecânica, supostamente neutro, mas com ressonâncias depreciativas, na recuperação que dele faz a Biologia. Michel Serres (1975) observa que tara tem duas acepções principais. Uma designa quantidade, o peso da embalagem que excede seu conteúdo, quando colocado sobre o prato da balança. Outra define qualidade (negativa), defeito transmissível. No emprego metafórico do termo feito por Zola e higienistas da época, os dois sentidos se congregam, para atestar que "a falta pesa", na forma de castigo de uma justiça (natural) distributiva. Nos discursos moralizantes da época acerca da hereditariedade, a tara, que percorre o sangue de todos os Rougon-Macquart, é associada à falta (faute). 


\section{A queda e a falta}

"A verdade proibida das origens", se está presente na narrativa de Zola, também nos é familiar com o mito da Queda de Adão e do Pecado Original. Ali também existe uma árvore, da qual Adão, o primeiro Homem, precisa manter distância, sob pena de desobedecer os desígnios de Deus.

De fato, como bem observa Gaillard (1994), a classe social que naquele momento nascia (a burguesia) tem como mito fundador a noção de "novo homem", sem passado, filho de suas obras (self-made man), que preza ocultar suas raízes (a verdade oculta das origens), diferentemente do que faz a aristocracia, que se empenha em ostentá-las em símbolos, como os brasões.

Aqui fica evidente a ligação entre a árvore genealógica (genética) e a Árvore do Conhecimento da tradição judaico-cristã, presente no mito do Gênesis. Seus frutos não devem ser tocados, sob pena de atrair para si todo o mal. E Pascal reenvia à sua sobrinha Clotilde a interdição outrora destinada a Eva, ao orientá-la a não tocar na árvore genealógica da qual este é fiel guardião, pois esta poderia revelar os segredos da família.

- "Ouves, Clotilde? Quando arranjares isto, não mexa nos papéis da prateleira de cima.

Está bem, mestre! - respondeu ela pela terceira vez docilmente.

Ele pusera-se a rir com o seu ar de natural alegria.

- É proibido!

- Bem sei, mestre!” (ZOLA, 1955, p. 8).

Zola cuida para que seu protagonista, Pascal, a despeito de sua proficiência científica, jamais conheça a verdadeira origem de todo o mal que assola os Rougon-Macquart, apesar de as culpas recaírem sobre tia Dide, cujo sangue viciado, circulando nas veias de todos os familiares, propagaria o infortúnio. "Mas não nos iludamos, os crimes que se gravaram no espírito já extinto da tia Dide nunca passam da consequência e da repetição de um crime anterior" (GAILLARD, 1994, p. 66) numa regressão infinita sem ponto de chegada e que nos remete ao primeiro crime da Humanidade, a falta/pecado original. Lição que reitera a noção de que não existe uma resposta possível a ser dada pela História para a questão das origens. Só o mito é capaz de fornecê-la.

Como sangue precisa ser reparado com sangue, tia Dide lança uma maldição contra o pequeno Carlos, sobrinho hemofílico, que será oferecido em holocausto 
à deusa Hereditariedade, para aplacar sua ira. "O sangue desse menino recairá sobre toda a minha descendência. Eu o sinto. Se eu sofri por vossa causa, vós sofrereis por causa minha, pois não há um de vós em cujas veias eu não tenha posto a desgraça”, afirma tia Dide, em certa passagem planejada do romance (MITTERRAND, 2001, p. 1.741).

Nessa história de pecado e redenção, o doutor Pascal (nome que agora ganha curiosas ressonâncias míticas) vê o saber (ciência?) cumprir perfeitamente sua função ideológica, erigindo a diferença (desigualdade) numa "lei da natureza e efeito da sua justiça”. Corre o risco de enlouquecer, pois imagina ter-lhe sido dada a missão de erradicar o infortúnio de sua família (ou, metaforicamente, recompor a igualdade social). Não percebera a hora certa de sair do palco onde este drama social da hereditariedade se desenrolava.

Pascal imagina-se o vetor da Redenção, do resgate dos homens, o que o converteria numa espécie de Cristo dos tempos modernos, "”o Segundo Adão", segundo o apóstolo Paulo, na perspectiva da tradição cristã.

Ele que dois meses antes se gabava tão triunfantemente de não ser da família, ia então receber o mais terrível dos desmentidos? Teria ele a dor de ver renascer em si a tara, precipitar-se ia no horror de se sentir nas garras do monstro hereditário? A mãe dissera-lhe: Enlouquecia de orgulho e de medo. A ideia soberana, a certeza exaltada que ele tinha de abolir o sofrimento, de incutir vontade aos homens, de refazer uma humanidade mais sadia e mais alta, isso tudo não era seguramente, do que o começo da mania de grandeza [...]. Todos os acidentes da raça iam dar a esse caso terrível: a loucura em curto prazo; depois a paralisia geral, e a morte (ZOLA, 1955, p. 130).

Pascal não compreendera que era mero figurante do drama burguês, destinado a propagar o evangelho da eternidade da desigualdade social. Isto quase o levará à loucura.

No leito de morte, Pascal, agora pacificado com a ordem natural das coisas, irá fazer um balanço de sua obra ao amigo Ramond.

Tinha a consciência nítida de não ter sido senão um pioneiro solitário, um precursor, esboçando teorias, tateando uma, praticando outra, naufragando por causa do seu método ainda bárbaro. Recordou o seu entusiasmo quando julgava ter descoberto a panacéia universal, com as suas injeçôes de substância nervosa, depois os seus desapontamentos, os seus desesperos, a morte brutal de Lafouasse, a tísica arrebentando Valentim, a loucura vitoriosa retomando Sarteur e enforcando-o. Por isso morria cheio de dúvida, não tendo já a fé necessária ao médico, tão amante da vida que acabara por por nela a sua última crença, certo de que a vida devia tirar só de si a sua saúde e a sua força. Mas não queria fechar o futuro, sentia-se feliz, pelo contrário, de legar sua hipótese à mocidade. De 20 em 20 anos as teorias mudavam, só ficavam 
inabaláveis as verdades adquiridas, sobre as quais a natureza continuava a edificar. Se mesmo não tivera o merecimento senão de trazer a hipótese do momento, o seu trabalho não ficaria perdido, porque o progresso estava seguramente no esforço, na inteligência sempre em marcha (ZOLA, 1955, p. 282).

À época de Zola, essa trama, curiosamente, só terá o primeiro ato: o da Queda/ Pecado (faute). A Redenção se manifestará, na interpretação que aqui realizamos, em 2005, com a divulgação de supostos avanços na Medicina Regenerativa, relacionada aos transplantes de células-tronco. É do que trataremos a seguir.

\section{O sangue e seus passados promissores}

O "retorno do recalcado" das representações ideológico-midiáticas acerca das recentes inovações biomédicas, e que corrobora, de alguma maneira, a análise sociocrítica aqui encetada em diálogo com Gaillard, atinge seu ápice em uma sugestiva imagem reproduzida em capa da revista Veja (figura 1).

É uma inequívoca alusão ao afresco intitulado $A$ criação de Adão, de Michelangelo (figura 2), pintado no teto da Capela Sistina, no Vaticano, entre 1508 e 1512. Só que, desta vez, o index que originalmente dá vida a Adão ostenta uma luva cirúrgica, numa ousada menção à pesquisa clínica com células-tronco adultas.

\section{Figura 2. A criação de Adão}

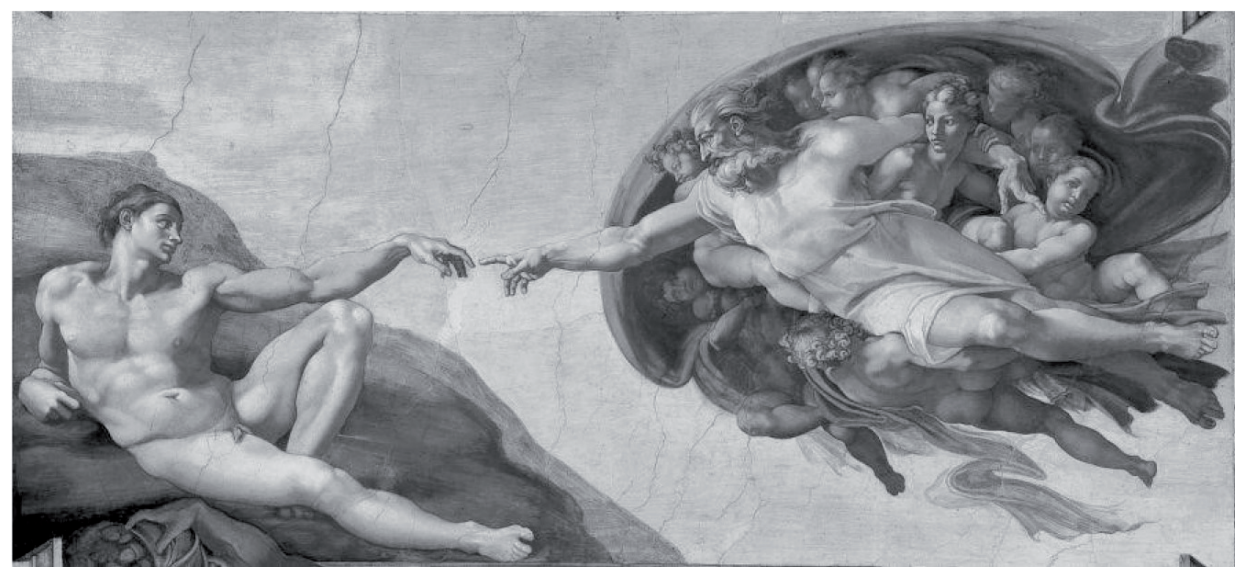

Fonte: Michelangelo: A criação de Adão. circa 1508-1512. Afresco. Capela Sistina, Vaticano. Retratada através de imagem em meio eletrônico 
A julgar pelo que essa capa quer nos dizer, se o Primeiro Adão caiu por conta do Pecado Original (ou, como vimos, pela falha genética, na biologia do século XIX), o Segundo Adão agora virá reabilitado pelo toque divinal da biomedicina, "que faz milagres" (como se pode ler na capa da revista em questão). Assim, como afirmado anteriormente, o discurso científico, de fato, (re)encontra sua coerência, graças ao mito matricial que está à sua disposição: o Genesis.

Aqui, a coprodução entre ordem natural e sociopolítica se dá através do emprego do que Ezrahi (2004) irá denominar "outformation", em oposição a "information" ("informação"). Outformations, segundo esse autor, constituiriam uma "configuração difusa de imagens, sons, narrativas e quadros", sem qualquer compromisso maior com uma representação confiável da realidade (ver figura 2) e que disputariam espaço na cultura de massas com imagens mais condizentes com a preocupação da ciência com objetividade e precisão. Lançando mão da clássica tipologia empregada em ciência da informação (dados, informação e conhecimento), o autor irá argumentar que o movimento que leva da information para a outformation representa "o sacrifício da profundidade e talvez também da precisão, em nome da acessibilidade".

O que gostaria de enfatizar é que este deslocamento representa uma mudança entre culturas alternativas de legitimação democrática. Talvez possamos discernir um deslocamento da legitimação que deriva de crenças e expectativas que suportam a noção de que decisões e ações não são arbitrárias quando fundamentadas, pelo menos em parte, em conhecimento ou informação acurada para uma legitimação derivada de certas constelaçôes de "outformations" (EZRAHI, 2004, p. 263).

Para Ezrahi, a aparente predileção do público contemporâneo por "outformations" revelaria sua propensão diminuída "a investir recursos individuais ou grupais na compreensão e definição da política e da gestão de assuntos públicos" (PUTNAM, 1995 apud EZRAHI, 2004).

\section{Conclusão}

Através do resgate histórico da constituição do discurso sobre a hereditariedade no século XIX e suas repercussões no imaginário da época, a partir de obra literária de um dos mais respeitados escritores franceses, Émile Zola, foi possível constatar a permanência de vestígios simbólico-míticos acerca da Genética que apontam para usos biopolíticos e estratégicos da esperança na contemporaneidade. Tais usos poderiam sinalizar uma nova governamentalidade da Biomedicina. 
Resultados preliminares desta investigação, que lançou mão do conceito de coprodução como vetor analítico, sugerem que a mediação social de corpos, patologias e identidades estaria sendo reconfigurada por conta de promessas terapêuticas associadas às células-tronco adultas. A combinação de "regimes de verdade", historicamente característicos da démarche científica, e "regimes de esperança", de matriz escatológico-religiosa, no debate público acerca do tema é retórica potente imbatível, posta a serviço da imposição de uma aceitação tácita de tecnologias emergentes no campo da Biomedicina, através do recurso engenhoso a outformations.

A representação midiática da biomedicina, neste caso, parece se pautar pela gestão habilidosa das emoções, através do emprego intensivo de outformations (EZRAHI, 2004), manobra possibilitada por uma espécie de pacto fáustico publicamente assumido, mas não declarado, entre ciência e mídia.

Cumpre destacar aqui que Ezrahi (2004) vê a proliferação de outformations, e de "realidades de baixo custo", na atualidade, como fato relativamente positivo, na medida em que sinalizaria que "a imaginação coletiva seria um meio mais participativo do que a razão pública para construir o universo político”. Isto, a seu ver, representaria uma "versão pós-moderna do contrato social". Se tais prognósticos podem ser acalentados nos países de alta renda sem maiores consequências, salvo melhor entendimento, as implicações de tais fabulaçooes midiáticas em países de renda média, como o Brasil, no que se refere à imaginação política (ideologia) democrática, mereceriam ser mais bem investigadas.

\section{Referências}

BARTHES, R. Mitologias. Rio De Janeiro: Editora Bertrand Brasil, 1993.

BIJKER, W. E.; HUGHES, T. P.; PINCH, T. J. The social construction of technological systems: new directions in the sociology and history of technology. Mit Press, 1987. 411.

BIRD, E.; DARDENNE, R. Mito, Registro e histórias: explorando as qualidades narrativas das notícias. In: TRAQUINA, N. (Ed.). Jornalismo: questôes, teorias e estórias. Lisboa: Ed. Vega, 1993. P.263-277.

BOWKER, G. C.; STAR, S. L. Sorting things out: classification and its consequences. Cambridge: Mit Press, 2000.

CAREY, J. A cultural approach to communication. In: (Ed.). Communication as culture: essays on media and society. Winchester, Uk: Unwin Hyman, Inc., 1975. P.13-36. 
CLARKE, A. Situational analysis: grounded theory after the postmodern turn. 1st.

Thousand Oaks, California: Sage Publications, Ltd., 2005. 365.

DURAND, G. As Estruturas antropológicas do imaginário. 3rd Ed. São Paulo: Martins Fontes, 2002. 551p.

EZRAHI, Y. The descent of Icarus: science and the transformation of contemporary democracy. Cambridge, Ma: Harvard University Press, 1990. 354p.

EZRAHI, Y. Science And the political imagination in contemporary democracies. In: JASANOFF, S. States of knowledge: the co-production of science and social order. New York. Routledge, 2004.

FAGOT-LARGEAULT, A.; KAHN, A. Biotechnologies et Transformation de l'homme. Entretien avec D. Rousseau. Les temps des savoirs, n. 2, s/p, 2000.

GAILlARD, F. Genèse et généalogie: le cas du Docteur Pascal. Romantisme. Paris 1981.

GAILLARD, F. Genética e mito da Gênese. In: . (Ed.). A Ciência e o imaginário. Brasília: Editora Unb, 1994. P.191p.

GAL, U.; YOO, Y.; BOLAND JR., R. The dynamics of boundary objects, social infastructures and social identities. Ecis 2005 Proceedings, 2005.

JASANOFF, S. The Idiom of co-production. In: JASANOFF, S. (Ed.). States of knowledge: the co-production of science and social order. New York: New York, 2004. Cap. 1, P.1-12.

LUCAS, P. Traité philosophique et physiologique de l'héredité naturelle. lere. Paris: Libraire De L'academie Royale De Médecine, 1847.

LULE, J. Daily news, eternal stories: the mythological role of journalism. New York: The Guildford Press, 2001.

LULE, J. News as myth: daily news and eternal stories. In: ROTHERBUHLER, E. W. E COMAN, Mihai (Ed.). Media Anthropology. Thousand Oaks, Ca: Sage, 2005. P.101-110.

MACKENZIE, D. Inventing accuracy: a historical sociology of nuclear missil guidance. Cambridge, Ma: Mit Press, 1990.

MAIA, F. D. Jornalismo e narrativa mítica: do ideológico ao imaginário. In: CONGRESSO DE CIÊNCIAS DA COMUNICAÇÃO NA REGIÃO SUL, XI. Novo Hamburgo: Sociedade Brasileira De Estudos Interdisciplinares De Comunicação - Intercom 2010.

MICHELET, J. Histoire de la Revolution Française. Paris. Éditions Gallimard, 1939. 1539p. MITERRAND, H. Préface. In: . (Ed.). Le Docteur Pascal. Paris: Éditions Gallimard, 1993. P.7-48.

MITTERRAND, H. Zola. Paris: Fayard, 2001.

PELLIZZONI, L. Construction, co-production and beyond. Academic disputes and public concerns in the recent debate on nature and society. Sociology Compass. 8: 851-64 P. 2014. 
PICHOT, A. La Génetique Est Une Science Sans Objet. Esprit, p. 102-131, Mai 2001.

PICKERING, A. The mangle of practice. Chicago: The University Of Chicago Press, 1995. PUTNAM, R. Tuning in, tuning out: the strange disappearance of social capital In America. The 1995 Ithiel De Sola Pool Lecture. Political Science And Politics, v. 27, p. 664-682, 1995.

SERRES, M. Feux et signaux de brume : Zola. Grasset, 1975. 379p.

SHAPIN, S.; SCHAFFER, S. Leviathan and the air-pump: Hobbes, Boyle, and the experimental life. 2011. Isbn 9780691150208.

STAR, S. L.; GRIESEMER, J. R. Institutional ecology, "translations" and boundary objects: amateurs and professionals in Berkeley's Museum of Vertebrate Zoology, 1907-39. Social Studies of Science, v. 19, issue 3, p. 387-420, 1989.

VATTIMO, G. O mito reencontrado. In: . (Ed.). A sociedade transparente. Lisboa:

Relógio D'água, 1992. Cap. 3, P.35-49.

ZOLA, E. O Doutor Pascal. São Paulo: Cia. Brasil Editora, 1955. 326p. . Le Docteur Pascal. Paris: Ed. Gallimard, 1993. 472p. 
Blood ties: heredity and coproduction of social and natural orders in the $19^{\text {th }}$ century

This article, based on a bibliographical review, seeks to establish relations between the scientific discourse on heredity, which emerged in the $19^{\text {th }}$ century, and a myth, which will provide the post-revolutionary bourgeoisie with an opportune symbolic weapon that will reconcile the notion of justice with the admission of the natural character of social inequality. Shaping itself perfectly to the myth of Genesis, Genetics, inscribing differences into a kind of natural justice, will play this role. So it is seen as a scientific theory presents itself as sublimation of the phantoms of a society. But if science wears them, fiction will undress them. For this reason, Émile Zola, whose novels deepen the mythical dimension of the statements of science, will have here one of his works analyzed. The result is that something comes to light that would otherwise remain hidden under the transparent mask of Science. Put another way, its unthinking, what it would not dare to verbalize: the notion that lack weighs.

Keywords: heredity; imaginary; coproduction; myth. 